\title{
Сороко Наталія Володимирівна
}

кандидат педагогічних наук, старший науковий співробітник

Інститут інформаційних технологій і засобів навчання Національної академії педагогічних наук України, м. Київ, Україна nvsoroko@rambler.ru

\section{МЕТОДИ ОЦІНЮВАННЯ ІНФОРМАЦЙНО-КОМУНІКАЦИЙНӦ̈ КОМПЕТЕНТНОСТІ ВЧИТЕЛІВ (ДОСВІД ЕСТОНІї)}

\begin{abstract}
Анотація. У статті розглядаються методиоцінювання інформаційно-комунікаційної компетентності вчителів загальноосвітніх навчальнихзакладів у контексті вивчення позитивного досвіду країн Європейського Союзу, зокрема Естонії. Розглядаються пропозиції естонських науковців щодо здійснення адекватного оцінювання ІКкомпетентності вчителів із використанням таких методів оцінювання як тестування, анкетування та вирішення завдань за сценаріями.
\end{abstract}

Ключові слова: інформаційно-комунікаційні технології; інформаційно-комунікаційна компетентність; оцінювання інформаційно-комунікаційної компетентності; підготовка вчителів; міжнародна діяльність.

Вступ. У сучасних умовах інформаційного суспільства підвищуються вимоги до інформаційно-комунікаційної компетентності (ІК-компетентності) вчителя, що визначається як здатність особистості відповідально, впевнено i критично застосовувати сучасні інформаційно-комунікаційні технології (ІКТ) для вирішення професійних, навчальних і наукових завдань та відповідні знання, навики та вміння застосовувати їх для практичної діяльності [1].

Суттєва роль у розвитку ІК-компетентності вчителя відводиться [2] оцінюванню та моніторингу цієї компетентності, оскільки дані процеси дають можливість виокремити основні проблеми та бар'єри щодо ефективного використання IКТ для підвищення якості професійної діяльності та кваліфікації вчителів.

У ході проведення досліджень у даній області були виділені і досліджені методи оцінювання ІК-компетентності вчителів загальноосвітніх навчальних закладів Естонії [2], як однієї з країн, в якій процес розвитку ІК-компетентності вчителів підтримується на державному рівні.

Метою статті $\epsilon$ опис методів оцінювання інформаційно-комунікаційної компетентності вчителів загальноосвітніх навчальних закладів за допомогою інформаційно-комунікаційних технологій в контексті вивчення позитивного досвіду країн Європейського Союзу (СС), на прикладі Естонії.

Аналіз останніх досліджень і публікацій. Питанням оцінювання інформаційнокомунікаційної компетентності вчителів присвячені роботи вітчизняних дослідників В.Ю.Бикова, М.І.Жалдака, Н.В.Морзе, О.В.Овчарук, С.О.Семерікова, О.В.Співаковського, О.М.Спіріна та ін., естонських науковців К.Тамметс (K.Tammets), М.Лаанпере (M.Laanpere), П.Нормак (P.Normak), К.Пата (K.Pata) та ін.

Для досягнення мети дослідження важливим $\epsilon$ розуміння основних базових понять, а саме: «оцінювання», «оцінювання ІК-компетентності», «методи оцінювання знань, вмінь і навичок».

Так, проаналізував роботи вищевказаних дослідників [3], ми пропонуємо розуміти оцінювання як систему, що охоплює методи, засоби i технології отримання i використання результатів об'єктивних педагогічних вимірювань освітніх досягнень тих, хто навчається, на певних етапах навчально-виховного процесу та при визначені професійної компетентності претендентів на професійну посаду і тих, хто працює. 
3 огляду на це та відповідно до визначення ІК-компетентності, що надається нами вище, оцінювання інформаційно-комунікаційних компетентностей охоплює [3]: готовність учасників навчального процесу використовувати IКТ; здатність суб‘єктів навчання застосовувати сучасні IКТ для вирішення професійних, навчальних i наукових завдань; відповідні знання, навички та вміння застосовувати їх для практичної діяльності.

При цьому, методи оцінювання знань, умінь і навичок, на наш погляд, слід розглядати як способи виявлення ефективності реалізації основних завдань навчання, а саме: засвоєння знань, умінь і навичок; оволодіння способами творчої діяльності; формування світоглядних і морально-естетичних ідей та цінностей [4].

Серед методів оцінювання знань, умінь і навичок виокремлюють [5]: спостереження за навчальною діяльністю, усну, письмову, практичну, тестову перевірки.

Для об’єктивного валідного оцінювання ІК-компетентності вчителів важливо підібрати такі методи оцінювання знань, умінь і навичок, які б дозволяли провести адекватний аналіз рівня цієї компетентності.

Одним із найбільш розповсюджених методів оцінювання ІК-компетентності в країнах $\mathrm{CC}$, зокрема Естонії, є сертифікація вчителів, а саме: видача сертифікатів «Міжнародні комп'ютерні права» (International Computer Driving Licence (ICDL)) та «Свропейські комп'ютерні права» (European Computer Driving Licence (ECDL)) вчителям, які успішно пройшли спеціальні тести [2]. Ці тести направлені на перевірку знань, вмінь і навичок за такими модулями: основи інформаційних технологій; робота на комп'ютері i керування файлами; текстовий редактор; електронні таблиці; використання баз даних; презентації; перегляд веб-сторінок і передача відомостей та даних за допомогою IКТ.

При цьому, естонські вчені М.Лаанпере, П.Нормак Т.Вьолятага, Х.Полдоя, К.Тамметс та ін. [6; 7] вважають, що для оцінювання ІК-компетентності вчителів таке тестування не достатньо відображає вміння вчителів доцільно, відповідально та критично використовувати ІКТ у своїй професійній діяльності. Вони стверджують, перш за все, що найбільш доцільними методами оцінювання ІК-компетентності вчителів є тестування, анкетування та вирішення завдань за сценаріями, що описують реальні професійні ситуації, в яких опиняються вчителі.

Орієнтуючись на дослідження Дж. Міллера (Miller, G.E.) щодо аналізу клінічних вмінь лікарів, вони, для створення тестів, анкет та завдань, дослідники [7] зосереджують увагу на таких позиціях:

- «знає» — основні факти (knows - basic facts);

- «знає, як» — прикладні знання (knows how — applied knowledge);

- «показує, як» - оцінка діяльності (shows how - performance assessment in vitro);

- «діє» - оцінка діяльності в реальних умовах (does - performance assessment in vivo). тестів:

Відповідно до вищезазначеного вчені [6] виокремлюють такі рівні щодо створення

- оцінювання другого рівня - «знає, як», що можна оцінити за допомогою тестів, в яких слід об'єднати застосування знань у професійній діяльності з великим діапазоном проблем;

- оцінювання третього рівня - «показує, як», що можна оцінити за допомогою іспитів практичного характеру;

- оцінювання четвертого рівня - «діє», оцінка якого потребує спостереження за людиною у її професійній діяльності [2]. 
У межах національного проекту Естонії DigiMina (DigitalMe in Estonian) [7], що був розпочатий згідно з державною програмою «Стрибок Тигра» (Tiger Leap), яка заснована відповідно до проекту Свропейського Союзу «Оцінювання та Навчання у галузі Навичок 21-го століття» (Assessment and Teaching of $21^{\text {st }}$ Century Skills (ATC21S) project (www.ATC21S.org)), вчені розробили он-лайн тести та завдання для самооцінювання й оцінювання ІК-компетентності вчителів.

Тести, анкети та завдання підібрані за такими сценаріями:

1. Майстер-студент оцінює свої знання, вміння, навички щодо володіння IКT;

2.Колеги оцінюють проблеми вирішення завдань за допомогою IКТ;

3.Вирішення вчителем професійних завдань за допогою IКТ;

4.Вирішення менеджером навчального закладу професійних завдань за допогою IKT.

Дослідження щодо формування тестових завдань проводяться відповідно до рішень наступних чотирьох науково-дослідних питань:

1. Які компоненти мають входити до структури цифрових інструментів відповідно до системи навчання у галузі використання ІКТ вчителями?

2. Які педагогічні підходи та теорії навчання будуть сприяти освіті у майбутньому за допомогою ІКТ?

3. Як реалізувати навчання за допомогою створення комп'ютерно орієнтованого середовища?

4. Як перевірити вплив он-лайн технологій на поведінку та навчання користувачів у межах комп'ютерно орієнтованого навчального середовища?

Тестові завдання вчені [7] розробили за трьома типами:

$$
\begin{array}{ll}
\text { - } & \text { тестові завдання для самооцінювання; } \\
\text { - } & \text { тестові завдання за рівнями компетентності; } \\
\text { - } & \text { тестові завдання щодо рефлексії. }
\end{array}
$$

Тестові завдання для самооцінювання примушують вчителя замислитися над питанням, які вміння і навички він має у галузі використання IКТ та які ще треба опонувати.

Наведемо приклад такого завдання [7]:

Завдання: «Виберіть, будь ласка, позицію. Яка описує Ваш рівень компетентності».

Відповіді:

«- створюю акаунт користувача в Веб-орієнтованих системах та наповнюю його ресурсами; користуюся програмами, Веб-середовищами, програмами для створення презентацій, друкування, копіювання та сканування матеріалів;

- управляю базами даних та розміщую їх у мережі Інтернет;

- вирішую проблеми використання ІКТ як інструментів для проведення форумів, надання та отримання у викладанні та навчанні;

- змінюю методи роботи відповідно до вимог Веб-середовища;

- вибираю найбільш доцільний інструмент для вирішення професійних завдань».

Тестові завдання за рівнями ІК-компетентності вчителів створювались згідно 3 такими виокремленими компонентами IК-компетентності [2]:

- управління інформацією (Information management), що охоплює знання, вміння і навички для пошуку необхідних відомостей i даних, їх аналізу та використанню відповідно до цілей педагогічної діяльності вчителя;

- співробітництво (Collaboration), що охоплює знання, вміння і навички, які $€$ необхідними для участі вчителів у он-лайн спільнотах та їх взаємодії з іншими користувачами у мережі Інтернет; 
- комунікація (Communication), що охоплює знання, вміння і навички вчителів для спілкування за допомогою он-лайн інструментів, з урахуванням конфіденційності, безпеки та мережевого етикету;

- створення контенту і знань (Creation of content and knowledge), що охоплює знання, вміння і навички особистості для творчої діяльності та створення нових знань через використання IКТ та попередніх знань і контентів, які поширюються за допомогою сервісів Інтернет;

- етика і відповідальність (Ethics and responsibility), що охоплює знання, вміння і навички особистості для належної поведінки в мережі Інтернет;

- оцінювання та рішення проблем (Evaluation and Problem-solving), що проявляється у доцільному підборі ІКТ для оцінювання і самооцінювання знань, вмінь і навичок із різних навчальних дисциплін та для вирішення проблем обробки результатів оцінювання за допомогою ІКТ і надання відповідної консультації;

- технічна операція (Technical Operation), що охоплює знання, вміння і навички особистості, які $\epsilon$ необхідними для ефективного, безпечного i правильного використання ІКТ у своєї професійної та навчальної діяльності.

Нижче, на рисунку 1, представлений приклад тестового завдання за рівнями IКкомпетентності вчителів.

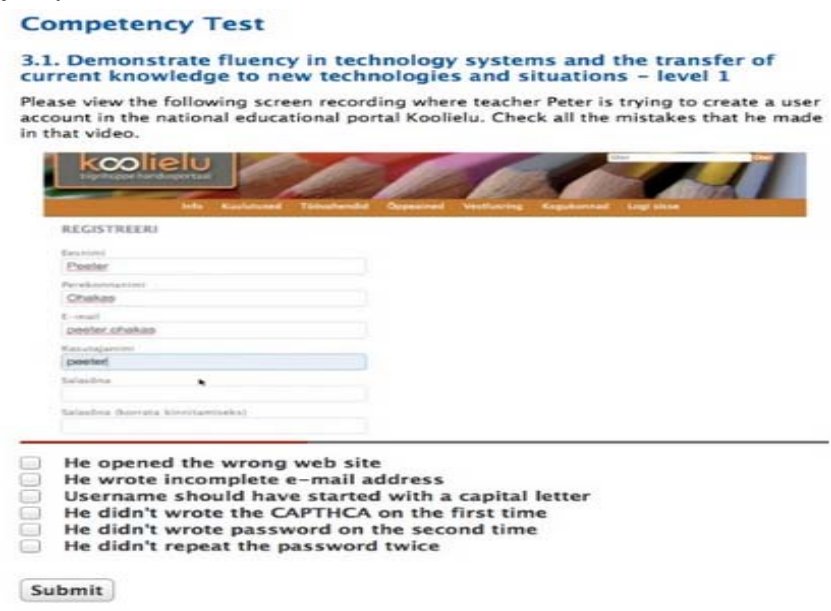

Рис. 1. Приклад тестового завдання за рівнями ІК-компетентності вчителів

Згідно з наведеним прикладом, тестове завдання складається 3 описаної реальної ситуації (наприклад, створення аканту на порталі освіти Естонії Koolielu.ee) та запропонованих шляхів вирішення проблем, які можуть виникнути у даній ситуації (наприклад, шляхи вирішення реєстрації на сайті, створення профілю на сайті, участь у форумі та ін.).

Тестові завдання на рефлексію так, як і вищеописані типи тестових завдань, базуються на виокремлених естонськими науковцями [7] компонентами ІКкомпетентності (управління інформацією, співробітництво, комунікація, створення контенту і знань, етика і відповідальність, оцінювання та рішення проблем, технічна операція) та складаються з проблемної ситуації й варіантів іiї розв'язання.

Результати тестування аналізуються за пятимірним оцінюванням:

I: якість вирішення завдань, які поділяються на значущі, актуальні, типові, складні;

II: володіння проблемою і їі рішення;

III: фізичний контекст, який полягає в оцінюванні професійного простору роботи та професійних інструментів;

IV: соціальний контекст, який відноситься до оцінювання професійної практики i якості прийняття рішень; 
V: форма, яка включає оцінювання демонстрації і презентації професійно значущих результатів.

Слід також відмітити, що особливого значення для процесу оцінювання ІКкомпетентності вчителів, набуває їх участь у міжнародних проектах, в межах яких пропонуються спеціальні курси, після проходження яких здійснюється тестування, анкетування, експертне оцінювання.

Так, естонські вчителі та наукові працівники у галузі педагогічних наук беруть активну участь у міжнародних проектах $\mathrm{CC}$, наприклад:

- ATC21S: Assessment and Teaching of 21st Century Skills - Оцінювання та навчання для навиків 21 століття (роки реалізації: 2009 р. - до наших днів, що триває при умовах оновлення завдань відповідно до аналізу результатів проекту );

- iTEC: Innovative Technologies for an Engaging Classroom (Grant agreement $\mathrm{N}^{\mathrm{o}}$ 257566) - Інноваційні технології для привабливого навчання (роки реалізації: 2010 р. 2014 p.);

- ESkills for jobs - електронні вміння для професій (роки реалізації: 2014 p. - 2020 p.);

- eTwinning: electronic Twinning - розвиток співробітництва європейських шкіл за допомогою ІКТ (роки реалізації: 2005 р. - 2015 р.);

- KeyCoNet: Key Competence Network - Ключова компетентність мережі IКТ (роки реалізації: 2012 р. - 2014 р.);

- SENnet: The Special Educational Needs Network - Освіта за допомогою ІКТ молоді з особливими потребами (роки реалізації: 2011 р. - 2020 р.);

- LangOER: Languages Open Educational Resources - Відкриті навчальні ресурси у галузі вивчення мов (роки реалізації: 2014 р. - 2016 р.);

- Go-LAB: Global Online Science Labs for Inquiry Learning at School - Світові онлайн лабораторії для науково-дослідної роботи у школі (роки реалізації: 2011 р. - 2015 p.);

- FCL: Future Classroom Lab - Майбутня навчальна лабораторія школі (роки реалізації: 2012 р. - 2015 р.);

- Scientix: the community for science education in Europe - співробітництво між вчителями, дослідниками, політиками та іншими фахівцями у галузях науки, технологій, інженерії та математики (STEM: science, technology, engineering and maths) (роки реалізації: перший етап: 2007 р. -2012 р.; другий етап: 2012 р. - 2015 р.);

- ins@fe Creative Classroom Lab ICT - Творча лабораторія з IKT (роки реалізації: 2012 p. -2015 p.).

У межах міжнародних поектах створюються педагогічно-організаційні умови для формування, розвитку та моніторингу, зокрема оцінювання, ІК-компетентності вчителів.

Нижче, на рисунку 2, наведена узагальнена таблиця щодо проведення оцінювання ІК-компетентності вчителів в Естонії. 


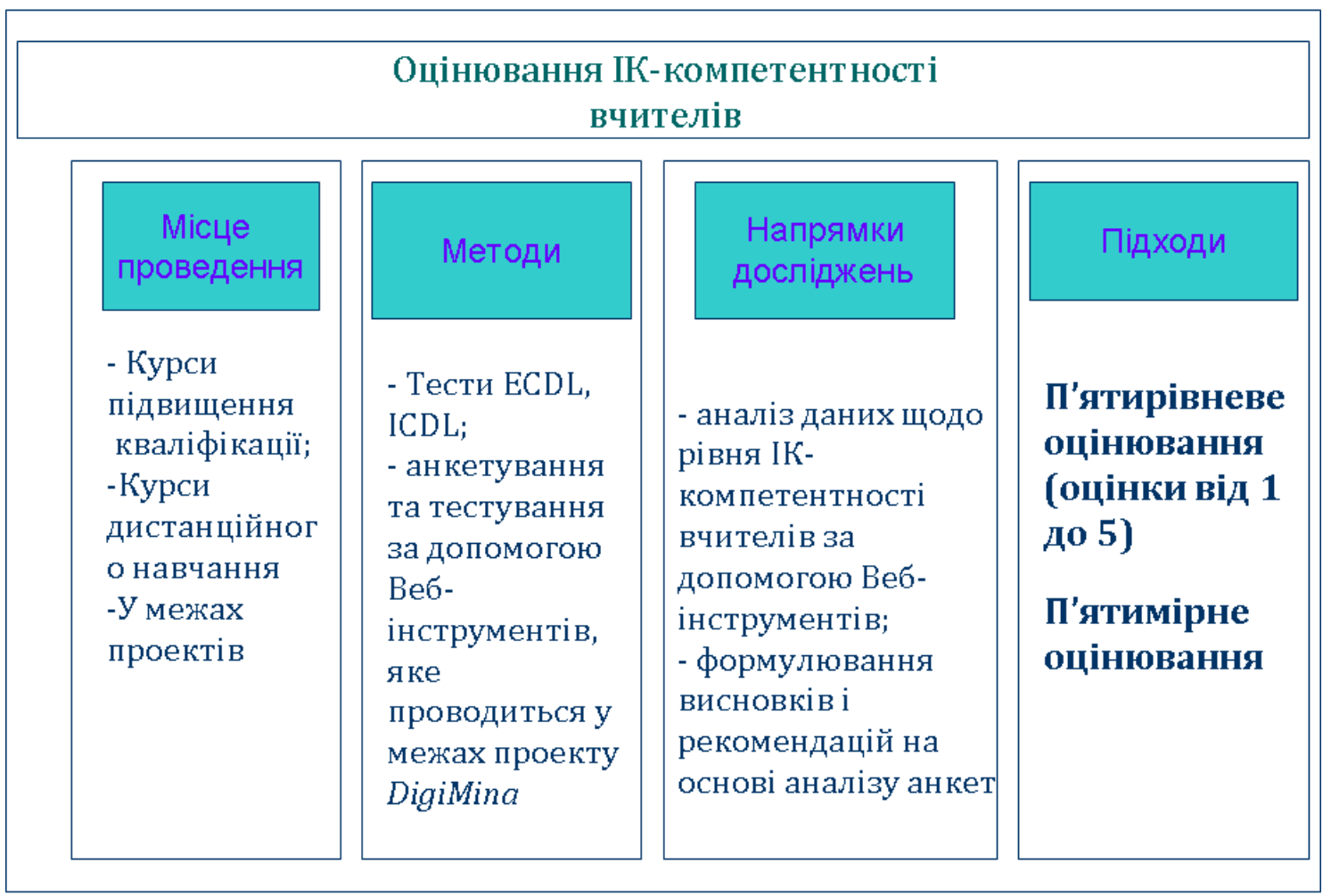

Рис.2. Узагальнена таблиця щодо проведення оцінювання ІК-компетентності вчителів в Естонії

Так, у вище наведеної узагальненої таблиці виокремлені такі позиції, як місце проведення оцінювання ІК-компетентності вчителів (курси підвищення кваліфікації, курси дистанційного навчання, у межах міжнародних та національних проектів); методи оцінювання (тестування ECDL, ICDL; анкетування та тестування за допомогою Веб-інструментів, яке проводиться у межах проекту DigiMina); напрями дослідження у галузі оцінювання (аналіз даних щодо рівня ІК-компетентності вчителів за допомогою Веб-інструментів; формулювання висновків і рекомендацій на основі аналізу анкет) та підходи до аналізу результатів тестування (пятирівневе оцінювання).

Висновок. Оцінювання IК-компетентності є важливим процесом для:

- з'ясування основних проблем, які виникають у вчителів при використанні IКТ у своїй професійній діяльності;

- розробки навчальних курсів у галузі ІКТ для вчителів для підвищення їх рівня ІК-компетентності;

- визначення оптимальних умов для використання IКТ у навчальних закладах;

- розробки якісної державної програми щодо розвитку ІК-компетентності вчителів та інформаційно-комунікаційної підтримки навчального процесу у школах;

- забезпечення політиків щодо розвитку ІК-компетентності вчителів, її еволюції протягом навчального року та виявлення потреб у цієї області.

При цьому оптимальними методами оцінювання ІК-компетентності вчителів, відповідно до досвіду Естонії, є тестування, анкетування та вирішення завдань за запропонованими сценаріями використання IКТ для різних завдань професійної педагогічної діяльності.

Крім цього, оцінювання ІК-компетентності вчителів $\epsilon$ основним етапом у вирішенні проблеми щодо сприяння збільшенню національного потенціалу країни в управлінні, випробуванні і політики щодо використання IКТ у загальноосвітніх навчальних закладах. 


\title{
СПИСОК ВИКОРИСТАНИХ ДЖЕРЕЛ
}

1. Сороко Н.В. Розвиток інформаційно-комунікаційної компетентності вчителів філологічної спеціальності в умовах комп'ютерно-орієнтованого середовища: дис. к-та пед. наук: 13.00.10/ Сороко Наталія Володимирівна, НАПН України, Інститут інформ. технологій і засобів навчання. - К., 2012. - 256 с.

2. Сороко Н.В. Використання ІКТ для оцінювання інформаційно- комунікаційної компетентності вчителів (досвід Естонії)// Наукові записки. -Випуск 5. - Серія: Проблеми методики фізико-математичної ітехнологічної освіти. Частина 1. Кіровоград: РВВ КДПУ ім.В.Винниченка, 2014 - 238с. - с. 55 - 61.

3. Овчарук О. В., Сороко Н. В. Загальні підходи до проблеми оцінювання інформаційно-комунікаційних компетентностей в системі освіти впродовж життя/ О. В.Овчарук, Н. В. Сороко/ Науковий часопис НПУ імені М. П. Драгоманова. Серія № 2. Комп“ютерно-орієнтовані системи навчання: Зб. наук. праць /Редрада. К.: НПУ імені М.П. Драгоманова, 2015. - № 16 (23). - 167 с., с. 145 - 148.

4. Гончаренко С. У. Український педагогічний словник / С. У. Гончаренко. - К. : Либідь, 1997. - 376 с., с. 206.

5. Виговська С.В. Педагогіка вищої школи: Метод. рекомендації - К.: Природничогуманітарний ННI Національного університету біоресурсів і природокористування України, 2011. - 164 с.

6. Mart Laanpere, Peeter Normak. Training teachers to become educational software developers. (2003). Journal of Digital Contents, 1(1), 146 - 150 p.

7. Hans Põldoja \& Terje Väljataga \& Mart Laanpere \& Kairit Tammets. Webbased self- and peer-assessment of teachers' digital competencies/Advances in Web-based Learning ICWL 2011: 10th International Conference, Hong Kong, China, December 8-10, 2011. Springer, 2011-334 p., pp. $122-131$.

\section{ASSESSMENT METHODS OF TEACHERS' INFORMATION- COMMUNICATION COMPETENCE (ESTONIA EXPERIENCE )}

\section{Natalia V. Soroko,}

$\mathrm{PhD}$ (pedagogical sciences), Senior Researcher

Institute of Information Technologies and Learning Tools of NAPS of Ukraine, Kyiv, Ukraine nvsoroko@rambler.ru

\begin{abstract}
The article discussed approaches to evaluation of teachers information and communication competence by using ICT in the context of the research the positive experience of the European Union (EU), for example in Estonia. There are considered Estonian researchers proposals to assessment methods of teachers information and communication competency.
\end{abstract}

Keywords: information and communication technology, information and communication competence, evaluation of information and communication competence, teacher training, international activity.

\section{REFERENCES (TRANSLATED AND TRANSLITERATED)}

1. Vygovska S.V. Higher Education Pedagogy: Method. Recommendations - The National University of Life and Environmental Sciences of Ukraine, 2011. - 164 p. (in Ukrainian).

2. Goncharenko S.U. Ukrainian Pedagogical Dictionary / S.U. Goncharenko. - Kyiv: Lybid, 1997. - 376 p., p. 206. (in Ukrainian).

3. Ovcharuk O.V., Soroko N.V. Common approaches to assessment of information and communication competence in lifelong learning / O.V.Ovcharuk, N.V. Soroko / Scientific journal of National Pedagogical Dragomanov University. Series № 2. 
Computer-oriented training system: Coll. Science. Labor / Redrada. - K.: National Pedagogical Dragomanov University, 2015. - № 16 (23). - 167 pp., p. 145 - 148. (in Ukrainian).

4. Soroko N.V. Using the Web tools for evaluation of teachers information and communication competence (Estonia experience)/ N.V. Soroko / Scientific notes. № 5. Series: Problems of methods for physical and mathematical and technological education. Part 1 - Kirovograd: Kirovohrad Volodymyr Vynnychenko State Pedagogical University, 2014 - 238 p. - p. 55 - 61. (in Ukrainian).

5. Soroko N.V. The development of information and communication competence of teachers philological specialty in computer-based oriented environment /Thesis of the Candidate of Pedagogical Sciences Degree, specialty 13.00.10 - Information and communication technologies in education. - Institute of Information technology and learning tools at NAPS of Ukraine, Kyiv, 2012. - 256 p. (in Ukrainian).

6. Mart Laanpere, Peeter Normak. Training teachers to become educational software developers. (2003). Journal of Digital Contents, 1(1), $146-150$ p.

7. Hans Põldoja \& Terje Väljataga \& Mart Laanpere \& Kairit Tammets. Webbased selfand peer-assessment of teachers' digital competencies/Advances in Web-based Learning - ICWL 2011: 10th International Conference, Hong Kong, China, December 8-10, 2011. - Springer, 2011-334 p., pp. $122-131$. 